\title{
Association immunohistochemical expression of Programmed Death-Ligand 1 (PD-L1) with degree Tumour Infiltrating Lymphocytes (TILs) as a prognosis factor in clear cell renal cell carcinoma and non clear renal cell carcinoma
}

\author{
Irmayani $^{\text {a }}$, Delyuzar ${ }^{\mathrm{b}}$, Lidya Imelda Laksmi ${ }^{\mathrm{c}}$, Joko S Lukito ${ }^{\mathrm{d}}$, Soekimin ${ }^{\mathrm{e}}$ \\ Department of Anatomical Pathology, Faculty of Medicine, Universitas Sumatera Utara, \\ Jalan Universitas No.1, Medan, Indonesia.
}

Corresponding author's e-mail: irmayanidr@gmail.com

\begin{abstract}
RCC) is a cancer originating from renal tubular epithelium and is known as a heterogeneous disease that includes different histological subtypes, CcRCC is the most frequent type and other renal epithelial malignancies as non ccRCC. The expression of PD-L1 in RCC can help to determine the prognosis of RCC patients who are known to be at high risk of having a poor prognosis. To assess the association between immunohistochemical expression of PD-L1 with the degree of TILS in patients with clear cell RCC and non clear RCC. PD-L1 immunohistochemical examination was performed on a fixed slide by using an H-score assessment of 26 samples of RCC and non clear RCC patients. Assessment of the degree of TILs is done on a slide with H\&E staining. In our study found that Immunohistochemical expression of PD-L1 was found positive in 20 cases $(76.9 \%)$ and negative in 6 cases $(23.1 \%)$. There was no significant association between immunohistochemical expression of PD-L1 with histological types of clear cell RCC and non clear cell RCC. Immunohistochemical expression of PD-L1 is strongly correlated with the degree of TILs, where the higher the degree of PD-L1, the lower the degree of TILs in RCC clear cells and non clear RCC cells. Conclusion: The relationship of immunohistochemical expression of PD-L1 correlates strongly with the degree of TILs, so it can be considered for prognostic examination on RCC and may be considered to be a target therapy for RCC.
\end{abstract}

Keywords: PD-L1, TILs, clear cell RCC, non clear cell RCC, RCC

\section{Introduction}

Renal cell carcinoma (RCC) is a cancer originating from the renal tubular epithelium. RCC represents $2-3 \%$ of all cancers, with the highest incidence occurring in western countries. During the last two periods to date, the incidence of RCC has increased by around $2 \%$ worldwide in Europe. $[1,2]$ In Indonesia, the overall incidence of RCC is estimated to reach $2.4-3$ cases/100,000 population, an increase from the previous results of $1.4-1.8$ cases/100,000 population.[3] The ratio of incidence between men and women is 1.5: 1, with peak events between the ages of 60 and 70 years. [1,2]

WHO classification of RCC tumors describes different categories and entities based on pathological and genetic analysis, this is important in determining prognosis and differential diagnosis. $[1,2] \mathrm{RCC}$ has been widely recognized as a heterogeneous disease that includes different histological subtypes. Clear-cell renal cell carcinoma (ccRCC) is the most common type, which is more than $80 \%$ of renal epithelial tumors. Other kidney epithelial malignancies, collectively referred to as non clear cell renal cell carcinoma (non-ccRCC), include subtypes of papillary renal cell carcinoma, chromophobe renal cell carcinoma as well as more rare forms such as unclassified renal cell carcinoma, and collecting duct renal cell carcinoma. Some studies conclude that non-ccRCC is more likely to have a worse prognosis than ccRCC. [1,4,5]

Programmed death ligand 1 (PD-L1) known as B7-H1 (CD274) is the first ligand for programmed death 1 (PD-1). PD-1 has 2 ligands, namely PD-L1 and PD-L2 which are members of the B7 family. PD-1 is known as an immune checkpoint whose function is to fight autoimmune by 2 mechanisms, namely apoptosis in specific $\mathrm{T}$ cells antigens in lymph nodes and decrease apopstosis in reg T cells including anti-inflammatory cells. Programmed cell death protein 1 (PD-1) is part of the CD28 family called a co-inhibitor receptor and acts as a negative immune system regulator. PD-1 and 
PD-L1 inhibitors are currently under investigation in terms of clinical development. [6,7,8] Some reports indicate that PD-L1 is associated with prognosis and therapy in various types of malignancies. Research on the prognostic significance of PD-L1 is relatively small in RCC, and the results are not entirely acceptable. Therefore it is necessary to analyze PD-L1 data on RCC to draw conclusions of detecting PD-L1 expression on RCC which may be very helpful in determining the prognosis of RCC patients known to be at high risk of having a poor prognosis. [8,9]

Research on immunohistokima PD-L1 expression as a prognostic factor for RCC, is currently the most widely performed type of clear cell renal cell carcinoma. Therefore, researchers are interested in investigating the expression of PD-L1 immunohistokima also in the type of non-clear cell renal cell carcinoma. In addition, researchers are also interested in assessing the relationship of PD-L1 immunohistochemical expression with TILs on ccRCC and non ccRCC.

\section{Material and methods}

We examined 26 cases of ccRCC and non-ccRCC sufferers at the Department of Anatomic Pathology, University of North Sumatra / Haji Adam Malik Hospital, Medan with a cross sectional approach. We collected clinical data, including age and sex. The grade and type of histopathology were evaluated by three researchers through microscopic examination of hematoxylin and eosin staining slides.

Immunohistochemical staining was carried out using PDL-1 with MD21R clone (Medaysis, CA). Positive control is placental tissue [12,13]. The claudin-7 expression was evaluated by three researchers using the $\mathrm{H}$-Score method. The $\mathrm{H}$ score formula to determine the total number of colored cells in each field and the number of cells colored with each intensity is as follows: HS $=(\%$ cells $3+)$ $\times 3+(\%$ cells $2+) \times 2+(\%$ cells $1+)$. The overall result is $0-300$, so the expression PD-L1 will be categorized as follows: $1=$ negative $(0-99), 2=$ positive $(100-300)$.[14]

\section{Result}

20 cases $(76.9 \%)$ and negative (0-99) in 6 cases (23.1\%) (Figure 1). In ccRCC, PD-L1 expression was positive in 17 cases $(65.0 \%)$ and PD-L1 expression was negative in 4 cases (15.3\%). In non ccRCC, PD-L1 expression was positive in 3 cases $(12.0 \%)$ and PD-L1 expression was negative in 2 cases (7.7\%) (Table 1). From 26 samples of this study, PD-L1 immunohistochemical outward expression was found to be positive (100-300) .

Table 1. Imunohistochemical expression of PD-L1 distribution in ccRCC and non ccRCC.

\begin{tabular}{ccccccc}
\hline & \multicolumn{4}{c}{ Ekpresi immunohistokimia $P D-L 1$} \\
\hline & \multicolumn{2}{c}{ Positif } & \multicolumn{2}{c}{ Negatif } & \multicolumn{3}{c}{ Total } \\
CcRCC & $\mathrm{n}$ & $\%$ & $\mathrm{n}$ & $\%$ & $\mathrm{n}$ & $\%$ \\
Non ccRCC & 17 & 65,0 & 4 & 15,3 & 21 & 80,7 \\
\hline Total & 3 & 12,0 & 2 & 7,7 & 5 & 19,3 \\
\hline
\end{tabular}
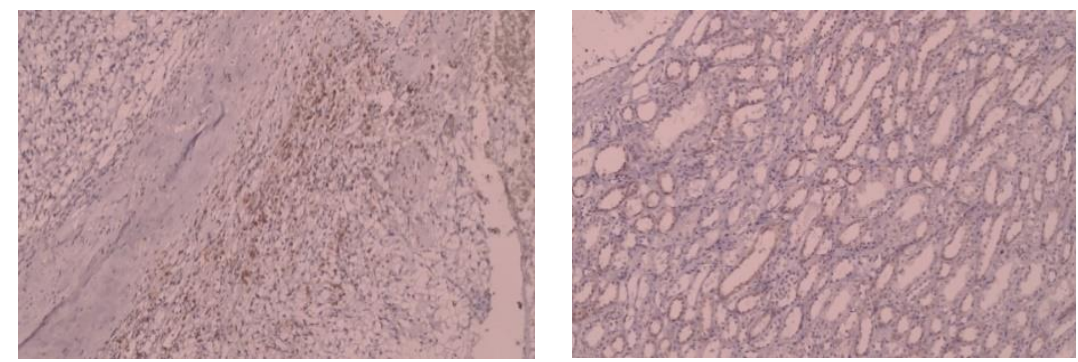

Figure 1. A. $P D-L 1$ positive in ccRCC. B. $P D-L 1$ positive in non ccRCC.

Based on clinical data obtained from medical records and anatomic pathology archives, the samples obtained in this study had an average age of 44.8 ( \pm 15.8$)$ years with the youngest age being 21 years 
and the oldest being 81 years. The most sex is male as many as 20 people $(76.9 \%)$ and followed by female sex as much as 6 cases $(23.1 \%)$. The histological type of all the study samples, found 21 cases $(80.8 \%)$ with ccRCC and 5 cases with non ccRCC including papillary renal cell carcinoma in 2 cases (7.7\%), followed by cases of chromophob renal cell carcinoma, collecting duct renal cell carcinoma, and uclassified renal cell carcinoma each in 1 case $(3.8 \%)$. This research uses ISUP and Fuhrman grading. A total of 17 cases (64.5\%) showed grade 4, followed by grade 3 as many as 7 cases (26.9\%), grade 2 as many as 2 cases (7.7\%), and there was no grade 1. Fuhrman's grading assessment results were obtained Most grading 4 is 19 cases (64.5\%) followed by grading 2 as many as 8 cases (30.8\%), and grading 1 is 1 case $(3.8 \%)$. The mean TILs were $5.0( \pm 1.76) \%$, with the lowest degree of $2 \%$ and the highest degree of $15 \%$. Tumors with TILs derajat $5 \%$ were 11 cases $(42.3 \%)$ and TILs\% $5 \%$ were 15 cases $(57.6 \%)$ (Table 2$)$.

Table 2. Sampel distribution with parameter clinikopathological of RCC

\begin{tabular}{|c|c|c|}
\hline & $\begin{array}{l}\text { Number of } \\
\text { case (n) }\end{array}$ & Persentase $(\%)$ \\
\hline Age, mean $\pm \mathrm{SB}$, tahun & \multicolumn{2}{|c|}{$44,8 \pm 15,8$} \\
\hline $21-35$ & 10 & 38,5 \\
\hline $36-50$ & 7 & 26,9 \\
\hline $51-65$ & 7 & 26,9 \\
\hline $66-80$ & 1 & 3,8 \\
\hline$>81$ & 1 & 3,8 \\
\hline \multicolumn{3}{|l|}{ Sex } \\
\hline Laki-Laki & 20 & 76,9 \\
\hline Perempuan & 6 & 23,1 \\
\hline \multicolumn{3}{|l|}{ Grading ISUP } \\
\hline Grade 1 & 0 & 0 \\
\hline Grade 2 & 2 & 7,7 \\
\hline Grade 3 & 7 & 26,9 \\
\hline Grade 4 & 17 & 65,4 \\
\hline \multicolumn{3}{|l|}{ Grading Fuhrman } \\
\hline Grade 1 & 0 & 0 \\
\hline Grade 2 & 1 & 3,8 \\
\hline Grade 3 & 8 & 30,8 \\
\hline Grade 4 & 17 & 65,4 \\
\hline \multicolumn{3}{|l|}{ Histological type } \\
\hline Clear Cell & 21 & 80,8 \\
\hline \multicolumn{3}{|l|}{ Non Clear Cell } \\
\hline Collecting Duct RCC & 1 & 3,8 \\
\hline Papillary $R C C$ & 2 & 7,7 \\
\hline Unclasified & 1 & 3,8 \\
\hline Chromophob RCC & 1 & 3,8 \\
\hline TILs stroma, mean $\pm \mathrm{SB}, \%$ & \multicolumn{2}{|c|}{$5,0 \pm 1,76$} \\
\hline$<5$ & 11 & 42,3 \\
\hline$\geq 5$ & 15 & 57,6 \\
\hline
\end{tabular}

The relationship between immunohistochemical expression of PD-L1 and the degree TILS of ccRCC and non-ccRCC has a significant correlation with the magnitude of the correlation being very strong and with a negative direction which means the higher the immunohistochemical expression of PD-L1 on ccRCC and non ccRCC, the lower the degree of TILs at ccRCC and nonccRCC and vice versa (Table 3).

Table 3. . Immunohistochemical expression of PD-L1 correlation test with degree of TILs on ccRCC and non ccRCC cells. 


\begin{tabular}{lccc}
\hline \multirow{2}{*}{ Variabel } & \multicolumn{3}{c}{ Degree of TILs } \\
\cline { 2 - 4 } & $\mathrm{N}$ & $\mathrm{r}$ & $P$ \\
\hline$P D-L 1$ pada $c c R C C$ & 21 & $-0,944$ & 0,0001 \\
\hline$P D-L 1$ pada non $c c R C C$ & 5 & $-0,979$ & 0,004 \\
\hline
\end{tabular}

${ }^{*}$ Immunohistochemical expression of PD-L1 correlation test with degree of TILs on ccRCC and non ccRCC.

\section{Discussion}

In this study it is known that based on the age distribution of patients found the youngest age is 21 years old while the oldest age is 81 years with an average age of $44.8 \pm 15.8$.. These results are the same as the results of research Melisa J, et al., Who conducted research during 3 years, stating that the most age is 51-65 years and the least is at age> 65.26 Josep et al., Getting the most age data from all RCC patients is $40-86$ years. [10]

From 26 samples of RCC sufferers, there were 20 men and 6 women. The data obtained is in accordance with previous research by Melisa et al. and Nguyen DP et al. which states that RCC is twice as common in men as women. This is also because RCC disease represents the 7th most common cancer in men and the 9th most common cancer in women. The strongest risk factors for RCC are smoking and smoking is more common in men than women and this might explain the higher proportion of men for RCC. [11,12]

In this study grading assessment is done by using both grading because the assessment has different parameters. Gruh Fuhrman displays an assessment of mitosis while ISUP grading does not display an assessment of mitosis that only focuses on the core child. The assessment using ISUP grading system in most RCC sufferers has grade 4, which is 11 cases and at least grade 2 is 2 cases. There is 1 case that does not have grading because it is not yet known which grading system is used in the histological collecting duct RCC type. The results of this study are almost in line with the research of Dagher et al. who used ISUP grading and found the majority of patients with grade 3. Research by Dagher et al. aims to compare the ISUP grading system and the Furhman system and there are differences between the two so that it can be used as a prognostic factor for predicting survival rates for patients with RCC. [13] Chandrasekaran et al., In the results of his research using ISUP grading found most RCC sufferers with grade 2, his research included several types of RCC histology namely clear cell RCC, ChRCC, PRCC, Collecting duct RCC, and Sarcomatoid. [14] Fuhrman grading assessment in this study found that the most grading 4 was $65.4 \%$ of cases and the smallest was grading 2 of $3.8 \%$ of cases. These results are in accordance with the results of Joseph RW, et al., Who examined the RCC case with the sarcoma component and obtained the most results, grading Fuhrman 4. [17] These results are different from the research of Kim HS, et al. who assessed Fuhrman's grading from a large number of RCC samples, 329 samples and no histological subtypes were mentioned and the highest grading was 1-2 grading. The difference in results is due to the large number of sample differences. [15]

The highest number of patients with RCC histopathology clear cell renal cell carcinoma type were 21 samples and the least was histopathology collecting RCC duct amounting to 1 sample. collecting duct RCC (1 sample), chRCC (1 sample), and unclassified (1 sample). The rest types of PRCC histology ( 2 samples). The results of this study are in accordance with the literature which states that the most histological type of RCC is the clear cell RCC. Melissa J, et al., In her research results stated that the most histopathological type in RCC is RCC clear cell. [11] Chandrasekaran et al., The results of his study also stated the same results, the results of his study that the clear cell RCC is the most histological type of RCC and the type of non-clear cell RCC histology each in 1 case. [14] In unclassified cases there is a component of squamous cell carcinoma (SCC). Unclassified type is a very rare type in RCC, in the study there was a histopathological picture outside the histopathological picture of the RCC subtype according to the RCC classification according to WHO in 2016. Histopathologically, the squamous component in kidney SCC is similar to other SCCs consisting of components of keratin pearls, intercellular bridges, and keratotic debris cells. [16] 
In this study, the mean number of TILs on RCC with positive PD-L1 expression was greater than the average number of TILs on RCC with negative PD-L1 expression. This result is almost the same as the study by Dillman, et al., Who assessed that the degree of TILs in the RCC found that the number of degrees of TILs> 5 was $11 \%$ of the sample. [19] The role of TILs in the RCC is still controversial. While there are studies on most other cancers showing a positive correlation between the number of TILs and prognosis. Several studies on RCC have shown that high density of CD8 + TILs correlates with poor clinical outcomes. [20] Nakano et al, showed that only the pre-proliferation of TILs showed a correlation with increased survival. Additionally, lymphocyte infiltration was found to correlate with higher tumor rates which might explain the negative correlation between $\mathrm{T}$ cell infiltration and survival. [21] Carlson J, et al. concluded from his research that the immunohystemical expression of PD-L1 in RCC tumor cells and TILs is associated with poor clinical outcomes and decreased RCC specific survival. [22] This difference is due to the TILs studied were TILs in tumor cells whereas in this study TILs were assessed in the stroma.

This research has a weakness that is the difficulty of researchers to determine the use of a grading system that can be used in all subtypes in this study. Grading assessment in this study was assessed based on previous studies. Until now the RCC grading system cannot be used for all RCC subtypes because RCC has many histological subtypes that have different morphology and prognosis so that the existing grading system is difficult to apply to all RCC subtypes.

\section{Conclusion}

Immunohistochemical expression of PD-L1 was found positive in 20 cases (76.9\%) and negative in 6 cases $(23.1 \%)$. Immunohistochemical expression of PD-L1 correlates strongly with the degree of TILs, where the higher the degree of PD-L1, the lower the degree of TILs in RCC clear cells and non clear RCC cells. It is advisable to carry out immunohistokima PD-L1 in patients with RCC as a consideration in providing additional therapy, namely PD-L1 inhibitors and conduct further research on PD-L1 as a prognostic factor associated with survival rates of patients with RCC.

\section{Acknowledgement}

We acknowledge all staffs and resident in the Department of Anatomical Pathology, University of Sumatera Utara/H. Adam Malik General Hospital, Medan, Indonesia for their help.

\section{References}

[1] Moch H, Amin MB, Argani P, Cheville J, Delahunt B, Martig G, et al. Renal cell tumour. In: Holger M, Peter A, Thomas M, Victor E, eds. WHO Classification of Tumours of the Urinary System and Male Genital Organs; 4th Ed. 2016. Lyon: IARC. 2016. pp13-74

[2] Ljungberg B, Bensalah K, Bex A, Canfield S, Dabestani S, Giles R.H, et al. Guidelines on renal cell carcinoma. European Association of Urology 2015. pp1-49

[3] Widia F. Clinical predictive factor of metastases in renal cell carcinoma. Fakultas Kedokteran Universitas Indonesia. 2015. pp1-7

[4] Jacquet SF, Deleuze A, Saout J, Mathieu R, Laguerre B, Verhoest G, et al. Targeting the PD1/PD-L1 Pathway in Renal Cell Carcinoma. Int. J. Mol. Sci. 2019, 20. pp1692

[5] Choueiri TK, Fay AP, Gray KP, Callea M, Ho TH, Albiges L, et al. PD-L1 expression in nonclear-cell renal cell carcinoma. Annals of Oncology 2015. pp2178-84

[6] Kythreotou A, Siddique A, Mauri AF, Bower M, \& Pinato DJ. PD-L1. J Clin Pathol. 2017. pp16

[7] Francisco ML, Sage TP \& Sharpe AH. The PD-1 pathway in tolerance and autoimmunity. Immunological Reviews 2010. Vol. 236. pp219-42 
[8] Jilaveanu LB, Shuch B, Zito CR, Parisi F, Barr M, Kluger Y. et al. PD-L1 Expression in Clear Cell Renal Cell Carcinoma: An Analysis of Nephrectomy and Sites of Metastases. 2014; 5(3). pp166-72

[9] Sholl LM, Asiner DL, Allen TC, Beasley MB, Borczuk AC, Cagle PT, et al. Programmed death ligand-1 immunohistochemistry- a new challenge for pathologists. Arch Pathol Lab Med. 2016; 140. pp341-44

[10] Joseph RW, Millis SZ, Carballido EM, Bryant D, Gatalica Z, Reddy S, et al. PD-1 and PD-L1 Expression in Renal Cell Carcinoma with Sarcomatoid Differentiation. Cancer Immunol Res; 2015. pp1-5.

[11] Melisa J, Monoarfa A \& Tjandra A. Profil penderita karsinoma sel ginjal (renal cell carcinoma) di RSUP Prof. Dr. R. D. Kandou Manado periode 2013-2015. Jurnal e-Clinic (eCl). 2016. Volume 4, Nomor 2.pp1-6

[12] NguyenDP, Vertosick EA, Corradi RB, Vilaseca A, Benfante NE, Touijer KA, et al.Histological subtype of renal cell carcinoma significantly affects survivalin the era of partial nephrectomy. Urologic Oncol. 2016; 34. pp1-7

[13] Dagher J, Delahunt, Rioux-leclercq N, Egevad L, Srigley J R, Coughlin, GSamaratunga, H. Clear cell renal cell carcinoma: Validation of WHO/ISUP grading. Histophatology, 2017. 71 (6). pp918-25

14] Chandrasekaran D, Sundram S, KAdhiresan N, PAdmavathi R. Programmed Death Ligand 1; An Immunotarget for Renal Cell Carcinoma. Asian Pac J Cancer Prev, 2019,20 (10). pp2951-57

[15] Kim SH, Park WS, Park EY, Park B, Joo J, Joung JY, et al. The prognostic value of BAP1, PBRM1, pS6, PTEN, TGase2,PD-L1, CA9, PSMA,and Ki-67 tissue markers in localized renal cell carcinoma: A retrospective study of tissue microarrays using immunohistochemistry.PLoS ONE 12. 2017 (6). pp1-11

[16] El Hachem G, Choueiry C, Al Hajj Obeid W, Chamseddine N. Renal Squamous Cell Carcinoma: Rare and Aggressive Variant of Renal Cancers. Cancer Biol Ther Oncol. 2017. Vol.1 No. 2:6. pp1-4

[17] Xing Y \& Hogquist KA. T-cell tolerance: central and peripheral. Cold Spring Harb Perspect Biol 2012. pp4-9

[18] Chen D.S, Irving B.A \& Hodi, F.S. Molecular pathways: Next-generation immunotherapyinhibiting programmed death-ligand 1 and programmed death-1. Clin. Cancer Res. 2012, 18. pp6580-87

[19] Dillman RO. Lymphocyte therapy of renal cell carcinoma. Expert Rev Anticancer 2005; 5(6). pp1041-51

[20] Remark R, Alifano M, Cremer I, Lupo A, Dieu-Nosjean M-CC, Riquet M, Crozet L, Ouakrim $\mathrm{H}$, Goc J, Cazes AA, et al. Characteristics and Clinical Impacts of the Immune Environments in Colorectal and Renal Cell Carcinoma Lung Metastases: Influence of Tumor Origin. Clin cancer Res [Internet] 2013 [cited 2013 Jul 11]; 19. pp4079-91

[21] Nakano O, Sato M, Naito Y, Suzuki K. Proliferative activity of intratumoral CD8C Tlymphocytes as a prognostic factor in human renal cell carcinoma: clinicopathologic demonstration of antitumor immunity. Cancer Res [Internet] 2001 [cited 2015 Jan 6]; 61. pp5132-36

[22] Liotta F, Gacci M, Frosali F, Querci V, Vittori G, Lapini A, Santarlasci V, Serni S, Cosmi L, Maggi L, et al. Frequency of regulatory $\mathrm{T}$ cells in peripheral blood and in tumour-infiltrating lymphocytes correlates with poor prognosis in renal cell carcinoma. BJU Int [Internet] 2011 [cited 2014 Dec 19]; 107. pp1500-06 